Journal of Animal and Veterinary Advances 10 (19): 2588-2592, 2011

ISSN: $1680-5593$

(C) Medwell Journals, 2011

\title{
Reproductive Performance and Milk Production of Girolando Cows in the Ranch of Kpinnou, South-West of Benin Republic
}

\author{
${ }^{1}$ Tbrahim Traore Alkoiret, ${ }^{1}$ Hadia Mama Yari, ${ }^{2}$ Armand Bienvenu Gbangboche and ${ }^{3}$ Richard Lokossou \\ ${ }^{1}$ Faculty of Agriculture, University of Parakou, P.O. Box 123, Parakou, Benin \\ ${ }^{2}$ Faculty of Agricultural Sciences, Abomey-Calavi University, P.O. Box 526, Cotonou, Benin \\ ${ }^{3}$ Project of Livestock Development III, Antenna of Kpinnou, P.O. Box 89, Lokossa, Benin
}

\begin{abstract}
Reproduction and milk production of Girolando cows raised in the ranch of Kpinnou were studied from 2005-2008. The traits recorded were: age at 1 st calving ( 92 records), calving interval ( 205 records), daily milk yield, peak milk yield, lactation yield ( 205 records), lactation length and dry period. The fixed factors tested were rate of blood $\mathrm{Gir}$, season of calving, lactation number, year of birth and year of calving. The overall mean of age at 1 st calving, calving interval, daily milk yield, peak milk yield, lactation yield, lactation length and dry period were respectively $35.3 \pm 0.4$ months, $468 \pm 14$ days, $7.2 \pm 0.2,12.3 \pm 0.2,1739 \pm 43 \mathrm{~kg}, 239 \pm 3$ days and $229 \pm 8$ days. The rate of blood Gir had a significant effect $(\mathrm{p}<0.05)$ on age at 1 st calving, daily milk yield and lactation yield but not significant ( $p>0.05$ ) on peak milk yield, lactation length and dry period. Lactation number, season of calving and year of calving significantly affected $(\mathrm{p}<0.05)$ all studied traits.
\end{abstract}

$\underline{\text { Key words: Calving season, age at } 1 \text { st calving, milk yield, Girolando, peakmilk, Benin Republic }}$

\section{INTRODUCTION}

Republic of Benin is located in Western Africa, bordering the Atlantic ocean. The country covers an area of $114000 \mathrm{~km}^{2}$ and has 8 million inhabitants from which $70 \%$ are agricultural workers. Agriculture contributes to $37 \%$ of GDP and over $85 \%$ of export earnings. Livestock production contributes to about $6 \%$ of national GDP. The cattle population is estimated to 1.9 million heads. This herd is made up of cattle breeds' Laguna, Somba and Borgou (31\%), zebu M'Bororo, Gudali and White Fulani $(8 \%)$ and their crossbreeds (61\%) (Dossou et al., 2006). Milk production of these breeds is low and varies from 1-2.5 $\mathrm{L}_{\text {day }}{ }^{-1}$ for a lactation length of 150-180 days (Dossou et al., 2006). The low productivity of these indigenous breeds cannot meet Beninese' needs in milk and the deficit is met through imports which economic implications are now a burden. The imports of milk and dairy products rose from 1.5 billion in 1993 to 20 billion $\mathrm{XOF}$ in 2008. However, average milk consumption in Benin is still low, even alarming not exceeding $20 \mathrm{~kg}$ per capita per year compared to the average of $34 \mathrm{~kg}$ in most developing countries and $50 \mathrm{~kg}$ recommended by FAO (Dossou et al., 2006). To reach this level of consumption, there is a need to increase national milk production threefold and this requires a modernization of Benin milk production. Thus, a breeding program focused on pure breeding, crossbreeding and dissemination of improved animals on farm has been established by the Project of Livestock Development in Samiondji ranch for Lagune cattle, Betecucu and Okpara ranches for Borgou. In addition, Girolando heifers were introduced from Brazil to Kpinnou ranch in 2004.

The aim of this study was to asses the effects of the rate of blood Gir, calving season, lactation number and year of calving on the reproductive performances and milk production of Girolando cows imported from Brazil-Benin Republic.

\section{MATERIALS AND METHODS}

Study area: The ranch of Kpinnou is located in the District of Athieme at latitude $6^{\circ} 33^{\prime}$ North and longitude $1^{\circ} 47^{\prime}$ East (South-West of Benin). The ranch is $400 \mathrm{~km}^{2}$ in area. The climate is of Guinean type with two dry seasons (January-March-S1 and August-September-S3) and two rainy seasons (April-July-S2 and October-December-S4). During the period of 1999-2009, the averages annual rainfall, temperature and relative humidity were respectively $1351 \pm 212 \mathrm{~mm}, 28.2 \pm 0.6^{\circ} \mathrm{C}$ and $73.4 \pm 1.9 \%$. March was the hottest month while December was the coolest of the year.

Animal management: Girolando (5/8 Holstein- $3 / 8 \mathrm{Gir})$ is a breed of dairy cattle created in Brazil by crossing Gir cattle, a Bos indicus breed which is resistant to hot

Corresponding Author: Ibrahim Traore Alkoiret, Faculty of Agriculture, University of Parakou, P.O. Box 123, Parakou, Benin 
temperatures and tropical diseases with Holstein (Bos Taurus). Girolando heifers were imported from Brazil to Kpinnou ranch in December 2004. The management pattern at the ranch of Kpinnou was semi intensive and the average annual herd size was 134 heads. The animals were grouped in four herds: milking cows, dry cows and heifers in gestation period, weaned calves, heifers and bulls. During the rainy season, the animals were put in rotation on artificial pastures of Panicum maximum and Andropogon gayanus. During the dry season, they were fed with hay of Brachiaria ruziziensis and silage made of Guatemala grass (Trypsacum laxum) and elephant grass (Pennisetum purpureum). In complementation, cows received $4 \mathrm{~kg}$ of concentrate per day during the morning milking at 6 am and the afternoon at 4 pm. Milking was done using a machine branded Alfa Laval. Water and salt lick were provided ad libitum. After calving, calves received colostrums from their dam at will for 2 or 3 days. Then they were separated from her and placed in individual calf pens where they received 3-5 L of milk per day until weaning at 16 weeks. Concentrates and forages were fed progressively from 10 th days until weaning. The natural mode of reproduction was adopted in the ranch of Kpinnou. The animals were regularly vaccinated against pasteurellosis, fever and contagious bovine pleuropneumonia. Each 3 months they were dewormed with albendazole and treated against trypanosomiasis. The animals were sprayed once a week during the dry season and twice a week during the rainy season against ticks. They were also screened for tuberculosis and brucellosis each year. Specific treatments were administered to each disease.

Data collection: Data were collected from the individual cow monitoring database. They covered the period from 2005-2008. For each cow identification number, date of birth, date of mating, date of calving and the identification number of the parent were recorded. Each cow also had a record collection of milk where the quantity of milk produced per day and per lactation was recorded. From the 105 age at 1 st calving and the 267 lactations initially collected only 92 age at 1st calving and 205 lactations were included. Data from cows which date of birth or calving and number of calving are unknown and lactation interrupted due to illness were excluded. The lactation length was evaluated from the collection of milk after calving until drying up. The dry period was calculated from the end of lactation until next calving. The calving interval represented the time recorded between two successive calving.

Statistical analysis: The traits analyzed were age at first calving (days), calving interval (days), daily milk yield (kg), peak milk yield (kg), lactation milk yield ( $\mathrm{kg}$ ), lactation length (days) and dry period (days). The fixed factors tested were rate of blood Gir, calving season, lactation number and year of calving. The year of birth was tested only on the age at 1 st calving. Data were analyzed using the General Linear Model (GLM) of SAS (2003), according to the linear fixed model below. Duncan's method was used to compare means when they were significantly different:

Where:

$$
\mathrm{Y}_{\mathrm{ijklm}}=\mu+\mathrm{G}_{\mathrm{i}}+\mathrm{S}_{\mathrm{j}}+\mathrm{P}_{\mathrm{k}}+\mathrm{C}_{1}+\varepsilon_{\mathrm{ijklm}}
$$

$\mathrm{Y}_{\mathrm{i} j \mathrm{klm}}=$ Alternatively represents one of the traits of the cow ijklm

$\mu \quad=$ Overall mean

$\mathrm{G}_{\mathrm{i}}=$ Fixed effect of the rate of blood Gir i $(\mathrm{i}=25,50$ and $62.5 \%$ )

$S_{j}=$ Fixed effect of calving season $j(j=S 1, S 2, S 3$, S4)

$\mathrm{P}_{\mathrm{k}}=$ Fixed effect of lactation number $\mathrm{k}(\mathrm{k}=1,2,3)$

$\mathrm{C}_{1}=$ Fixed effect of the year of calving $1(1=2005$, $2006,2007,2008)$ or year of birth $1(1=2002,2003$, 2005,2006 for age at 1 st calving)

$\varepsilon_{\mathrm{ijklm}}=$ Random error effect

\section{RESULTS AND DISCUSSION}

The rate of blood Gir had a significant effect $(\mathrm{p}<0.05)$ on age at 1 st calving and insignificant $(p>0.05)$ on calving interval (Table 1). Age at 1 st calving was higher $(p<0.05)$ in cows with $50 \%$ blood Gir and lower $(\mathrm{p}<0.05)$ in those with $62.5 \%$ of blood Gir. Age at 1st calving is closely

Table 1: Least square mean $\pm \mathrm{SE}$ of age at 1 st calving (months) and calving interval (days) of Girolando cows in the ranch of Kpinnou, Benin Republic

\begin{tabular}{|c|c|c|}
\hline Sources of variation & Age at 1st calving & Calving interval \\
\hline Overall mean & $35.3 \pm 0.4(92)$ & $468.4 \pm 13.6(205)$ \\
\hline \multicolumn{3}{|c|}{ Rate of blood Gir (\%) } \\
\hline 25 & $34.9 \pm 1.3^{b}(16)$ & $470.2 \pm 16.2^{a}(45)$ \\
\hline 50 & $36.8 \pm 0.4^{\mathrm{a}}(62)$ & $464.0 \pm 9.0^{\circ}(146)$ \\
\hline 62.5 & $29.2 \pm 0.4^{c}(14)$ & $509.5 \pm 8.40^{\mathrm{a}}(14)$ \\
\hline \multicolumn{3}{|l|}{ Calving season } \\
\hline $\mathrm{S} 1$ & - & $482.1 \pm 14.5^{\mathrm{ab}}(68)$ \\
\hline $\mathrm{S} 2$ & - & $445.5 \pm 10.3^{b}(48)$ \\
\hline S3 & - & $437.4 \pm 11.0^{b}(30)$ \\
\hline S4 & - & $487.2 \pm 16.0^{\mathrm{a}}(59)$ \\
\hline \multicolumn{3}{|l|}{ Lactation number } \\
\hline 1 & - & $526.3 \pm 13.5^{\mathrm{a}}(92)$ \\
\hline 2 & - & $432.5 \pm 04.7^{\mathrm{b}}(81)$ \\
\hline 3 & - & $393.3 \pm 02.6^{c}(32)$ \\
\hline \multicolumn{3}{|c|}{ Year of birth or calving } \\
\hline 2002 & $38.5 \pm 0.5^{\mathrm{a}}(34)$ & - \\
\hline 2003 & $34.7 \pm 0.4^{b}$ & - \\
\hline 2005 & $30.3 \pm 0.3^{c}(8)$ & $543.8 \pm 26.3^{a}(31)$ \\
\hline 2006 & $27.7 \pm 0.4^{c}(6)$ & $507.4 \pm 18.1^{a}(54)$ \\
\hline 2007 & - & $435.5 \pm 05.5^{b}(77)$ \\
\hline$\underline{2008}$ & - & $424.3 \pm 07.1^{\mathrm{b}}(43)$ \\
\hline
\end{tabular}


J. Anim. Vet. Adv., 10 (19): 2588-2592, 2011

Table 2: Least square mean $\pm \mathrm{SE}$ for daily milk y ield (kg), peak milk yield (kg), lactation y ield (kg), dry period (days) and lactation length (days) of Girolando cows in the ranch of Kpinnou, Benin Republic

\begin{tabular}{|c|c|c|c|c|c|c|}
\hline Sources of variation & $\mathrm{N}$ & Daily milk yield & Peak milk y ield & Lactation yield & Dry period & Lactation length \\
\hline Overall mean & 205 & $7.2 \pm 0.2$ & $12.3 \pm 0.2$ & $1739 \pm 43$ & $229.0 \pm 8.10$ & $239.3 \pm 3.00$ \\
\hline \multicolumn{7}{|c|}{ Rate of blood Gir (\%) } \\
\hline 25 & 45 & $8.0 \pm 0.3^{\mathrm{a}}$ & $13.1 \pm 0.5^{\mathrm{a}}$ & $1928 \pm 61^{a}$ & $226.3 \pm 18.7^{\mathrm{a}}$ & $243.9 \pm 6.10^{\mathrm{a}}$ \\
\hline 50 & 146 & $7.1 \pm 0.2^{b}$ & $12.1 \pm 0.3^{\mathrm{a}}$ & $1727 \pm 55^{b}$ & $224.2 \pm 9.60^{\mathrm{a}}$ & $239.6 \pm 3.60^{\mathrm{a}}$ \\
\hline 62.5 & 14 & $5.7 \pm 0.4^{c}$ & $11.4 \pm 0.6^{\mathrm{a}}$ & $1255 \pm 95^{c}$ & $287.4 \pm 14.6^{a}$ & $222.1 \pm 13.1^{\mathrm{a}}$ \\
\hline \multicolumn{7}{|l|}{ Calving season } \\
\hline S1 & 68 & $6.7 \pm 0.3^{a}$ & $11.1 \pm 0.4^{a}$ & $1548 \pm 70^{a}$ & $252.1 \pm 15.9^{a}$ & $230.0 \pm 5.80^{\mathrm{a}}$ \\
\hline $\mathrm{S} 2$ & 48 & $7.6 \pm 0.4^{b}$ & $12.9 \pm 0.5^{b}$ & $1795 \pm 94^{b}$ & $209.5 \pm 12.5^{b}$ & $235.9 \pm 6.40^{\mathrm{a}}$ \\
\hline S3 & 30 & $7.4 \pm 0.2^{b}$ & $13.9 \pm 0.5^{\mathrm{bc}}$ & $1916 \pm 82^{b}$ & $180.8 \pm 12.6^{b}$ & $256.7 \pm 5.20^{b}$ \\
\hline S4 & 59 & $7.5 \pm 0.3^{b}$ & $12.3 \pm 0.4^{b}$ & $1822 \pm 85^{b}$ & $242.6 \pm 16.8^{a b}$ & $244.1 \pm 5.40^{\mathrm{ab}}$ \\
\hline \multicolumn{7}{|l|}{ Lactation number } \\
\hline 1 & 92 & $5.9 \pm 0.2^{\mathrm{a}}$ & $10.3 \pm 0.3^{\mathrm{a}}$ & $1367 \pm 48^{a}$ & $295.6 \pm 14.1^{\mathrm{a}}$ & $230.4 \pm 5.00^{\mathrm{a}}$ \\
\hline 2 & 81 & $8.1 \pm 0.3^{b}$ & $13.1 \pm 0.4^{b}$ & $1967 \pm 69^{b}$ & $190.1 \pm 6.00^{b}$ & $242.4 \pm 4.50^{\mathrm{a}}$ \\
\hline 3 & 32 & $8.7 \pm 0.2^{b}$ & $15.9 \pm 0.3^{c}$ & $2229 \pm 47^{c}$ & $135.8 \pm 5.30^{c}$ & $257.4 \pm 5.20^{b}$ \\
\hline \multicolumn{7}{|l|}{ Year of calving } \\
\hline 2005 & 31 & $5.9 \pm 0.3^{\mathrm{a}}$ & $10.3 \pm 0.5^{\mathrm{a}}$ & $1438 \pm 74^{a}$ & $298.2 \pm 26.8^{a}$ & $244.6 \pm 7.70^{\mathrm{ab}}$ \\
\hline 2006 & 54 & $6.2 \pm 0.3^{\mathrm{a}}$ & $10.3 \pm 0.4^{\mathrm{a}}$ & $1412 \pm 77^{a}$ & $283.2 \pm 19.2^{\mathrm{a}}$ & $224.2 \pm 6.70^{\mathrm{a}}$ \\
\hline 2007 & 77 & $7.7 \pm 0.2^{b}$ & $13.3 \pm 0.3^{b}$ & $1963 \pm 68^{b}$ & $183.5 \pm 6.60^{b}$ & $252.0 \pm 4.00^{b}$ \\
\hline 2008 & 43 & $8.5 \pm 0.3^{c}$ & $14.5 \pm 0.5^{c}$ & $1964 \pm 84^{b}$ & $192.5 \pm 11.5^{b}$ & $231.9 \pm 6.70^{\mathrm{a}}$ \\
\hline
\end{tabular}

${ }^{\mathrm{a}-\mathrm{c}}$ Least square mean with different superscript letters on the same column differ significantly $(\mathrm{p}<0.05)$

related to the age at puberty which varies according to breed, season, feeding and rearing conditions (Schillo et al., 1983; Mohamed et al., 2010). Cows with $62.5 \%$ of blood Gir were born at Kpinnou ranch and had certainly benefited from improved farming conditions enabling them to have an age at 1 st calving shorter. The effect of calving season on calving interval was significant $(\mathrm{p}<0.05)$ and animals born during the seasons $\mathrm{S} 2$ and S3 had got the shortest $(\mathrm{p}<0.05)$ calving interval (Table 1). These seasons would provide cows the best feeding conditions enabling them to return quickly to heat to be fertilized again. In most studies, calving during warm seasons adversely affected reproduction in dairy cattle (Ray et al., 1992; Moore et al., 1992; Farin et al., 1994; Silva, 1998). Lactation number significantly $(\mathrm{p}<0.05)$ affected Girolando cows calving interval (Table 1) which declined with increasing lactation number from 1-3 tending toward the threshold of 365 days or one calf per cow per year, optimum lens of temperate dairy cattle (Coleman et al., 1985). In general, first parity cows required longer calving interval than the third or above parity cows (Goshu et al., 2007). This may be due to the additional nutritional requirements of cows in early lactation life for growth. Year of birth had significant effect $(p<0.05)$ on age at 1 st calving and year of calving significantly affected $(\mathrm{p}<0.05)$ the calving interval (Table 1). The effect of the year on these reproductive parameters can be attributed to variations in rainfall conditioning forage resources, the basis of feeding the Girolando cows at the ranch of Kpinnou.

The rate of blood Gir had a significant effect $(p<0.05)$ on daily milk yield and lactation yield which declined with the increase of blood Gir but not significant $(\mathrm{p}>0.05)$ on peak milk yield, lactation length and dry period (Table 2 ).
This is in agreement with the findings of other reseachers in Brazil (Madalena et al., 1990; Freitas et al., 1998; Faco et al., 2002) who reported that increasing the proportion of Holstein-Friesian genes did not have any significant effect on milk yield when herds were raised under poor management conditions. Calving season was a source of significant variation $(\mathrm{p}<0.05)$ for daily milk yield, peak milk yield, lactation yield, lactation length and dry period (Table 2). Thus, the season S2, S3 and S4 had fostered a better $(\mathrm{p}<0.05)$ milk production. Season S3 which corresponded to the short dry season (AugustSeptember) gave the best $(\mathrm{p}<0.05)$ peak milk yield (Table 2). Lactation peak coincided to season S4 (small rainy season) during which the harmattan (dry and cool wind), creating a mild climate similar to the ones in Brazil. Similar effect of calving season on milk production of dairy cattle has been observed (Ray et al., 1992; Silva et al., 1992; Moore et al., 1992). Lactation number had a significant effect $(\mathrm{p}<0.05)$ on daily milk yield, peak yield, lactation yield, lactation length and the dry period (Table 2). Milk production of Girolando cows increased $(p<0.05)$ while the dry period decreased $(p<0.005)$ with lactation number from 1-3. Year of calving significantly affected $(\mathrm{p}<0.05)$ the daily milk yield, peak yield, lactation yield, lactation length and dry period (Table 2). The effect of the year on milk production of Girolando cows can be attributed to changes in climatic conditions (rainfall, temperature) from 1 year to another.

Reproductive performance and milk production of Girolando cows at the ranch of Kpinnou are lower than those of Brazil. Analysis of data (1996-2004) from 3282 lactations of Girolando cows revealed that age at 1st calving, calving interval, 305 days milk yield and lactation length averages were 34 months, 420 days, $3349 \mathrm{~kg}$ and 
272 days, respectively (Freitas et al., 2006). The overall mean of daily milk yield observed here $\left(7.2 \mathrm{~kg} \mathrm{day}^{-1}\right)$ was higher than the ones reported by Freitas et al. (1998) on Brazilian crossbred dairy cows $\left(6.9 \mathrm{~kg} \mathrm{day}^{-1}\right)$. On the other hand, it was lower than the average of $10.1 \mathrm{~kg} \mathrm{day}^{-1}$ obtained by Mackinnon et al. (1996) and the $13.1 \mathrm{~kg}$ day $^{-1}$ reported by Faco et al. (2002) for five HolteinxGir genetic groups raised under different feeding system in Brazil. The low performances of Girolando cows in Benin Republic may be related to climate of Kpinnou ranch, characterized by high temperature and relative humidity. These two factors in addition to radiation and wind can influence the degree of heat stress (Jordan, 2003). Heat stress is one of the main causes that decreases dry matter intake and feed digestion (Morand-Fehr and Doreau, 2001), reduces the efficiency of milk yield (West, 2003; Bohmanova et al., 2008; Molee et al., 2011) and reduces the fertility (Jordan, 2003). The results can also be explained by the infectious diseases of reproduction such as retained placenta, endometritis, vulvovaginitis and other pathologies such as lumpy skin disease, foot and mouth disease, mastitis and gastrointestinal parasites. The effect of nutrition on reproduction and milk production of dairy cows could also be considered. There were seasonal and annual variations in the quantity and quality of forage available to feed the cows at the ranch of Kpinnou. Moreover, the availability and quality of concentrates and silage were also varied over time. Heat stress and different diseases, coupled with inappropriate and infrequent interventions have contributed to lower milk production performance of dairy cows at Kpinnou ranch.

\section{CONCLUSION}

The study showed that reproductive performance and milk production of Girolando cows at the ranch of Kpinnou are lower than those of Brazil, their mother country. The rate of blood Gir led to lower milk production and reduction of age at first calving especially in Girolando cows born in Benin Republic. A significant improvement in all traits was noted with increasing lactation number from 1-3. Significant variations of studied traits due to year and season of calving were noticed.

Thus, the calving season S3 resulted in the best reproductive performance and milk production. Calving schedules may be adjusted to minimize the adverse effect of heat stress. These results may serve as a basis for selection for increased milk production of the Girolando herd at the ranch of Kpinnou.

\section{ACKNOWLEDGEMENT}

The researchers thank the Livestock Development project for permission to carry out this study.

\section{REFERENCES}

Bohmanova, J., I. Misztal, S. Tsuruta, H.D. Norman and T.J. Lawlor, 2008. Short communication: Genotype by environment interaction due to heat stress. J. Dairy Sci., 91: 840-846.

Coleman, O.A., W.V. Thayne and R.A. Dailey, 1985. Factors affecting reproductive performance of dairy cows. J. Dairy Sci., 68: 1793-1803.

Dossou, J., S. Hounzangbe-Adote, H. Soule and B.I. Chabi, 2006. Production and processing of fresh milk into Fulani cheese in Banin. Good Practice Guide. GRET-CAD/FSA, pp: 33.

Faco, O., R.N.B. Lobo, R.M. Filho and A.A. Moura, 2002. Analysis of productive performance of different Holstein x Gir genetic groups in Brazil. R. Bras. Zootec., 35: 1944-1952.

Farin, P., B. Slenninq, M. Correa and J. Britt, 1994. Effects of calving season and milk yield on pregnancy risk and income in North Carolina Holstein cows. J. Dairy Sci., 77: 1848-1855.

Freitas, A., M. Freitas, N. Teixera and C. Costa, 2006. Additive genetic and heterosis effects on milk yield and fertility of Girolando cows. Proceedings of the 8th world Congress on Genetics Applied to Livestock Production, Aug. 13-18, Brazil, pp: 1-57.

Freitas, A.F., C.J. Wilcox and C.N. Costa, 1998. Breed group effects on milk production of brazilian crossbred dairy cows. J. Dairy Sci., 81: 2306-2311.

Goshu, G., K. Belihu and A. Berihum, 2007. Effect of parity, season and year on reproductive performance and herd life of Friesian cows at Stella private dairy farm, Ethiopia. Livest. Res. Rural Dev., 19: 23-30.

Jordan, E.R., 2003. Effects of heat stress on reproduction. J. Dairy Sci., 86: E104-E114.

Mackinnon, M.J., W. Thorpe and R.L. Baker, 1996. Sources of genetic variation for milk production in a crossbred herd in the tropics. Anim. Sci., 62: 5-16.

Madalena, F.E., A.M. Lemos, R.L. Teodoro, R.T. Barbosa and J.B.N. Monteiro, 1990. Dairy production and reproduction in Holstein-Friesian and Guzera crosses. J. Dairy Sci., 73: 1872-1886.

Mohamed, A.A., I.A. Babiker and A.E. Eltayeb, 2010. Effect of concentrate supplementation on growth and sexual development of dairy heifers. J. Applied Sci. Res., 6: 212-217. 
Molee, A., B. Bundasak, P. Kuadsantiat and P. Mernkrathoke, 2011. Suitable percentage of Holstein in crossbred dairy cattle in climate change situation. J. Anim. Vet. Adv., 10: 828-831.

Moore, R.B., J.W. Fuquay and W.J. Drapala, 1992. Effects of late gestation heat stress on postpartum milk production and reproduction in dairy cattle. J. Dairy Sci., 75: 1877-1882.

Morand-Fehr, P. and M. Doreau, 2001. Effects of heat stress on feed intake and digestion in ruminants. INRA Prod. Anim., 14: 15-27.

Ray, D.E., T.J. Halbach and D.V. Armstrong, 1992. Season and lactation number effects on milk production and reproduction of Dairy cattle in Arizona. J. Dairy Sci., 75: 2976-2983.

SAS, 2003. SAS/STAT User's Guide, Version 9.1. SAS Institute Inc., Cary, $\mathrm{NC}$, USA.
Schillo, K.K., P.J. Hanzen, L.A. Kamwandja, D.J. Dierschke and E.R. Hauser, 1983. Influence of season on sexual development in heifers: age at puberty as related to growth and serum concentrations of gonadotropins, prolactin, thyroxine and progesterone. Biol. Reprod., 28: 329-341.

Silva, H.M., C.J. Wilcox, W.W. Thatcher, R.B. Becher and D. Morse, 1992. Factors affecting days open, gestation length and calving interval in Florida dairy cattle. J. Dairy Sci., 75: 288-293.

Silva, W.J., 1998. Changes in reproductive performance of Holstein dairy cows in Kentucky from 1972 to 1996. J. Anim. Sci., 76: 244-252.

West, J.W., 2003. Effects of heat-stress on production in dairy cattle. J. Dairy Sci., 86: 2131-2144. 